\begin{tabular}{|l|l|l||}
\hline \multicolumn{2}{|c|}{ PublisherInfo } \\
\hline \hline PublisherName & $:$ & BioMed Central \\
\hline \hline PublisherLocation & $:$ & London \\
\hline \hline PublisherImprintName & $:$ & BioMed Central \\
\hline \hline
\end{tabular}

\title{
NSAIDs reduce Alzheimer's independently of COX activity
}

\begin{tabular}{|l|l|l||}
\hline \multicolumn{2}{|c|}{ ArticleInfo } \\
\hline \hline ArticleID & $:$ & 290 \\
\hline \hline ArticleDOI & $:$ & $10.1186 /$ ar-2002-74550 \\
\hline \hline ArticleCitationID & $:$ & 74550 \\
\hline \hline ArticleSequenceNumber & $:$ & 43 \\
\hline \hline ArticleCategory & $:$ & Paper Report \\
\hline \hline ArticleFirstPage & $:$ & 1 \\
\hline \hline ArticleLastPage & $:$ & 3 \\
\hline \hline & & RegistrationDate : 2002-1-15 \\
ArticleHistory & $:$ & Received \\
\hline \hline ArticleCopyright & $:$ & Biomed Central Ltd2002 \\
\hline \hline ArticleGrants & $:$ & \\
\hline \hline ArticleContext & $:$ & 130754411 \\
\hline \hline
\end{tabular}


Affl Imperial College Faculty of Medicine, London, UK

\section{Keywords}

Alzheimer's disease, COX inhibitor, ibuprofen, sulindac sulphide

\section{Context}

Nonsteroidal anti-inflammatory drugs (NSAIDs) are commonly used in the treatment of rheumatoid arthritis. NSAID users have previously been shown to have a reduced risk of developing Alzheimer's disease. The deposition of the 42-residue isomer of the amyloid-? peptide (A?42) is central to the pathogenesis of Alzheimer's disease. A?42 is generated by cleavage of the amyloid precursor protein (APP) by a ?-secretase that cleaves APP at different positions thereby generating peptides of different lengths. This study investigates the mechanism through which NSAIDs exert their protective effect against the development of Alzheimer's disease.

\section{Significant findings}

CHO cells, which do not normally express APP, were transfected with APP and a presenilin mutant that leads to elevated levels of A? peptide production. Treatment of these cells with the nonselective cyclooxygenase (COX) inhibitors sulindac sulphide, ibuprofen or indomethacin, led to a 50-70\% decrease in A?42 levels. However, not all NSAIDs were capable of reducing A?42 levels: the nonselective COX inhibitor naproxen, the COX-2 specific inhibitor celecoxib and the COX-1 specific and COX-2 preferential inhibitors aspirin and meloxicam respectively all had no effect on A?42 levels, indicating that the A?42-lowering effect is independent of COX activity. Indeed, fibroblasts deficient in both COX-1 and COX-2 exhibited reduced levels of A?42 in response to sulindac sulphide. Ibuprofen, but not naproxen, also reduced brain A?42 levels by $39 \%$ in a mouse model of Alzheimer's disease. Mass spectrometric analysis showed that the reduction in A?42 levels following sulindac sulphide treatment was associated with a dose-dependent increase in the level of another APP-derived peptide A?(1-38). Therefore, NSAIDs are thought to subtly alter the activity of the APP-cleaving ?-secretase.

\section{Comments}


One may not expect to see a study identifying a potential cure for Alzheimer's disease reported within Arthritis Research, however it is of interest to the arthritis community as it identifies both a novel use and site of action for some NSAIDs. This novel mechanism can account for the epidemiological observation that NSAID users have a reduced risk of developing Alzheimer's disease, which was recently confirmed by a large trial (see Additional information). It had previously been thought that the anti-inflammatory properties of NSAIDs were responsible for this reduced risk, acting via COX inhibition; however, this study clearly demonstrates that the protective mechanism is independent of COX activity and potentially acts via a ?-secretase. Further investigation is required to establish the precise mechanism by which amyloidogenic peptide levels are reduced by certain NSAIDs. As more specific COX-2 inhibitors become available for the treatment of rheumatoid arthritis, the beneficial COX-independent effects of these broad-acting therapies must not be forgotten.

\section{Methods}

ELISA, western blotting, immunoprecipitation with mass spectrometry (IPMS)

\section{Additional information}

in 't Veld BA, Ruitenberg A, Hofman A, Launer LJ, van Duijn CM, Stijnen T, Breteler MMB Stricker BHC: Nonsteroidal anti-inflammatory drugs and the risk of Alzheimer's disease. $N$ Eng $J$ Med 2001, 345: 1515-21.

\section{References}

1. Weggen S, Erikson JL, Das P, Sagi SA, Wang R, Pietrzik CU, Findlay KA, Smith TE, Murphy MP, Bulter T, Kang DE, Marquez-Sterling N, Golde TE, Koo EH: A subset of NSAIDs lower amyloidogenic A?42 independently of cyclooxygenase activity. Nature. 2001, 414: 212-216.

This PDF file was created after publication. 